\title{
The Rev. John Kerr, F.R.S., Inventor of the Kerr Cell
}

\author{
By Dr. Robert C. Gray
}

$\mathrm{O}^{\mathrm{N}}$ $\mathrm{NE}$ of the many problems in television reception is that of modulating the brightness of the spot of light that, travelling very rapidly over the screen, gives the sensation of a completely moving picture. In one system a neon lamp is used, and the brightness of the lamp is varied by the incoming signals being allowed, after suitable amplification, to alter the voltage across the lamp. A neon lamp is not very bright, compared with a filament or arc lamp ; and the next development was the use of a bright lamp, the brightness of the beam of light being altered after the light had left the lamp.

The first experimenters who tried this latter method found that the necessary apparatus was already available in the Kerr cell; it had been invented in 1875 by a Glasgow man, and had been lying for more than fifty years awaiting a practical application.

John Kerr was born

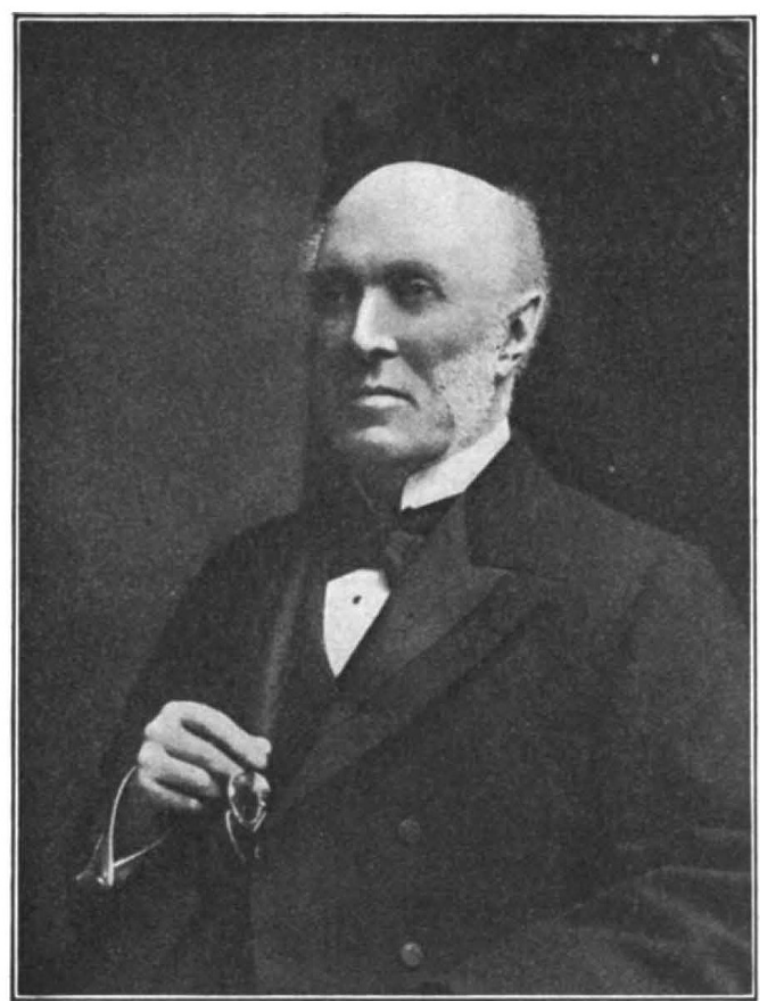

FIG. 1. The Rev. John Kerr, M.A., LL.D., F.R.S. (1824 1907). twenty-two years old, a friendship that was to last for more than sixty years until their deaths, within four months of one another, in 1907. Kerr continued his studies in physics under Thomson for three more years, gaining special prizes, in successive years, on the subjects of "The Mathematical Theory of Magnetism", "The Mathematical Theory of Electricity", and "The Distribution of Electricity on Spherical Conductors". He graduated master of arts in 1849 , eight years after his first matriculation, "with Highest Distinction in Mathematics and Natural Philosophy", and was awarded the Earl of Eglinton's Prize of twenty sovereigns as the most distinguished student in mathematics and natural philosophy. $\mathrm{He}$ engaged in teaching for some time, and was ordained to the ministry of the Free Church of Scotland, but did not preach very often.

In 1857 Kerr was appointed lecturer in mathematics and physical science in the Free at Ardrossan, Ayrshire, on December 17, 1824. He was the second son of Thomas Kerr, who owned a fleet of fishing vessels, and he received part of his education in a village school in Skye. He entered the University of Glasgow in 1841 as a divinity student, and took the usual classes for the degree of master of arts. During the session 1845-46, he took the class of natural philosophy, when it was taught during the illness of Prof. Meikleham by David Thomson, afterwards professor of natural philosophy at Aberdeen. In 1846 William Thomson, who later became Lord Kelvin, was appointed to the chair of natural philosophy. William Thomson was only six months older than Kerr, and there sprang up a close friendship between these two young men, professor and student, each Church Training College for Teachers, Glasgow. In 1863 he published a pamphlet entitled "The Metric System : its Prospects in this Country", and in 1867 a book on what he called "Rational Mechanics". In the following year the senate of the University of Glasgow, on the recommendation of Profs. Thomson and Blackburn, conferred on Kerr the honorary degree of doctor of laws.

From 1848, Prof. Thomson was gradually converting what had been the old professorial winecellar into a physical laboratory for students, the first in the world. Thomson invited his students to help him in his measurements, and Kerr was one of the earliest members of the pioneer team, composed, strangely enough, mostly of divinity students. This experimental training under an 
enthusiastic leader had a great influence--as such training generally has-on Kerr's after-life, and when he joined the teaching staff of the training college, he utilised a cellar there for experimental work. Afterwards he worked in the basement of his house. He was fifty-one years of age when in $\mathbf{1 8 7 5}$ he made his first and most important contribution to science, by a publication, in the

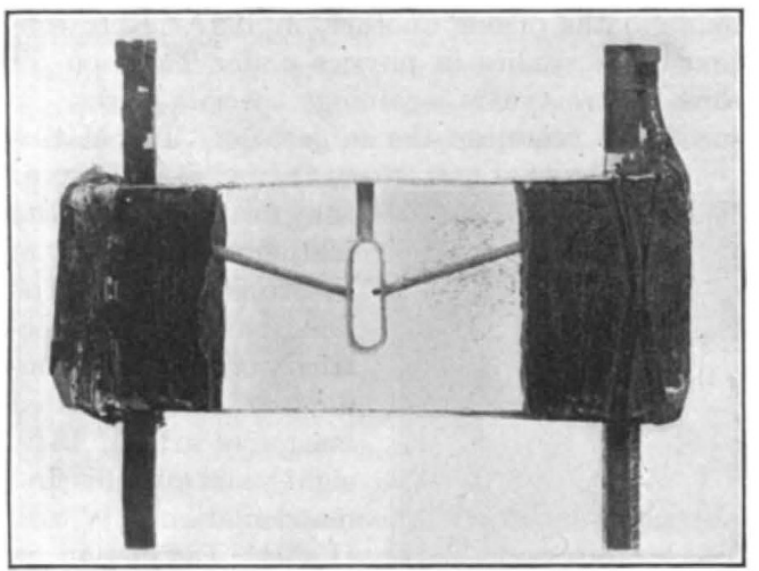

Fig. 2. The first Kerr cell, used by Dr. John Kerr in his discovery of the Kerr electro-optic effect.

Philosophical Magazine, of the discovery of what came to be known as the Kerr electro-optic effect. It is this effect that is utilised in the Kerr cell used in television reception. Faraday in 1834 thought that this effect might exist; he tried to detect it, but failed. William Thomson in 1845 suggested that it might be worth while to search

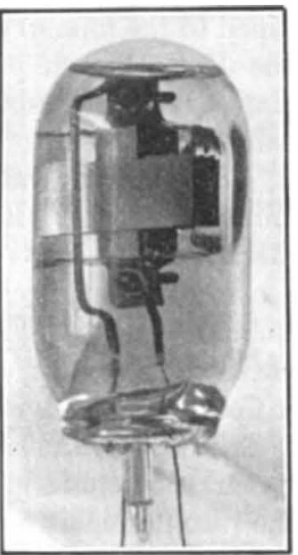

FIG. 3. Kerr cell (1935) as sed by Baird Television, Ltd., in television reception. for the effect ; his attention was directed to Faraday's negative result, and he abandoned the idea. Thirty years later, Kerr looked for the effect, and found it, first in glass, later in certain liquids.

The original piece of apparatus with which Kerr detected the effect in glass was a simple slab of glass, measuring six inches by three inches, and three quarters of an inch thick; two collinear holes, each an eighth of an inch in diameter, were drilled from the two ends, parallel to the long edges, the ends of the holes being about half an inch apart. Down each of these holes was passed a wire from one pole of an induction coil, and polarised light was passed from one face of the slab to the opposite face. When the induction coil was operated, Kerr found, as he expected, that the glass had become doubly refracting. He followed up this discovery by searching for, and finding, the same result in liquids. The original cells that he used are in the care of the University of Glasgow, and a photograph of the first cell used for liquids is reproduced as Fig. 2. For comparison, a photograph of a modern Kerr cell is also reproduced (Fig. 3). In the original Kerr cell, the cavity in the centre was closed at the sides by plates of glass, and was filled with liquid through the channel drilled from the top; wires that carried the varying electric potential will be seen passing down the sloping holes; polarised light was passed through the liquid from one side of the slab to the other. In the modern Kerr cell, the voltage is applied between two sets of alternate plates; the liquid used is nitrobenzene, and the light is passed through the liquid in a direction parallel to the planes of the plates. When in 1898 Lord Lister, president of the Royal Society, was presenting a Royal Medal to Dr. Kerr, Lord Lister said: "It has been a matter of admiration and wonder to subsequent investigators that Dr. Kerr should have been able to learn so much with the comparatively simple and ineffective apparatus at his disposal". It is related that Dr. Kerr, then seventy-four years old, was much peeved at Lister's remarks: "Simple it may be," he protested, "but not ineffectire ; rude, but not crude".

In 1876 the British Association met in Glasgow, and Kerr read a paper on his second discovery, the Kerr magneto-optic effect, which has been of much importance in the theory of magnetism. Altogether Kerr published, between 1875 and 1901, only ten papers, but each is of permanent value. In 1890 he was elected a fellow of the Royal Society, and in the following year Sir Arthur Rücker, speaking at the British Association, referred to Kerr's outstanding discoveries and said: "The generations which reap the harvest which earlier students of the science of electricity have sown will not forget the name of Dr. Kerr as that of a physicist who completed in the laboratory of a training college a chain of evidence of which Faraday and Maxwell had forged the first links". In $\mathbf{1 8 9 8}$ the Royal Society awarded him the Royal Medal, now in the Hunterian Museum of the University of Glasgow. At the dinner that followed the presentation of medals, Sir Oliver Lodge, who had been awarded the Rumford Medal at the same time for his researches in radiation, replied for the medallists ; speaking of Dr. Kerr, he said that Dr. Kerr had made two first-class discoveries in science, and his name would go down to posterity linked with these discoveries for all time; ten centuries later the Anglo-American race would know and remember the name of their medallist, John Kerr. Kerr retired from his lectureship at 
the Training College in 1901 after forty-four years' service. His country recognised his work by giving him, in 1902, a Civil List pension of $£ 100$ a year. He died on August 18, 1907, three months before Lord Kelvin, in his eighty-third year.

Dr. Kerr was a well-built man, over six feet in height, of attractive and lovable personality. The late Prof. Andrew Gray wrote of him : "The name of this quiet and unostentatious teacher and experimentalist will be linked for all time with that of Faraday. He would not himself have desired any better immortality"; and Prof. Magnus Maclean, who had been a student under Kerr and is still with us, said at Kerr's retirement : "No one could have passed through Dr. Kerr's class without observing and being influenced by the singular simplicity, the sincerity and the lovableness of his character".

\section{The Draft Poisons List and Poison Rules}

\section{The Chemical Manufacturer and the Chemist}

\section{Interpretation of the Rules}

$\mathrm{T}$ HE report of the Poisons Board together with the draft Poisons List and Poison Rules, which was discussed in NATURE of June 22, p. 1013, raises a number of questions of detail of interest to many besides the pharmacist. The more important of these questions are those which affect the chemical manufacturer particularly, and those which concern the profession of chemistry as a whole.

The first set of questions was considered at a meeting convened by the Association of British Chemical Manufacturers on July 4, which was attended by Mr. M. D. Perrins, secretary of the Poisons Board, to discuss the interpretation of the draft Poisons List and Rules. At the outset, Mr. Perrins pointed out that the only real distinction between Part I and Part II of the Poisons List, that between poisons which can be sold by retail to the general public by authorised sellers of poisons, that is, by registered pharmacists, and those which can be so sold only by listed sellers and authorised sellers of poisons, does not affect the sales with which the chemical manufacturer is concerned. The distinction between substances in the First Schedule and those which are not is, generally speaking, that those in the First Schedule have various restrictions applied to them, such as that the purchaser must be known to the seller and a record must be kept. On the other hand, for practical purposes, the only restriction on substances not in the First Schedule is that they must be labelled in accordance with the Act and Rules and they must be in the type of container required by the Rules.

Mr. Perrins also pointed out that preparations sold by manufacturers to doctors or veterinary surgeons more or less in bulk do not come under the heading of medicines 'made up ready', and emphasised that the Rules are to be administered by those who could be trusted to act with commonsense. The view taken in the report of the Departmental Committee is that the control of poisons is such an intricate and complicated matter, so liable to change, that it is impossible to deal with it by restrictions set out in an Act of Parliament. Much elasticity is necessary and questions of control must be dealt with by regulations which can be altered from time to time. Should it be found, for example, that these Rules work harshly on the trade in a particular raw material which does not in practice afford any danger to anyone, a fact which may have been overlooked, then that can be dealt with by a Rule adding it to the general exemptions or special exemptions as may be required.

In the discussion which followed, a number of points were raised in regard to the detailed interpretation of the Rules. It was emphasised that there are no responsibilities placed on the manufacturer as to whom he sells poisons, provided he does not sell them by retail to members of the public.

The question of abbreviated names was raised, the abbreviations used in the British Pharmacopœia being regarded as official, and it was suggested that the Association should recommend that the ordinary abbreviated names used in the trade should be considered to be accepted scientific names, a proposal which will not commend itself to the profession of chemistry generally. Various questions relating to transport and labelling were raised, but as the Report itself emphasises, the Board does not propose to include any industrial poisons in the List solely on the ground of the possibility of danger arising during transit, in view of the rules to be issued under the Petroleum 